\title{
Late Miocene-Early Pliocene Planktonic Foraminifera and Palaeoceanography of the North Atlantic
}

\author{
PETER W. P. HOOPER', BRIAN M. FUNNELL ${ }^{2}$ and PHILIP P. E. WEAVER ${ }^{3}$ \\ 18 Edward Avenue, Bishopstoke, Eastleigh, Hants SO5 6EG \\ ${ }^{2}$ School of Environmental Sciences, University of East Anglia, Norwich NR4 7TJ \\ ${ }^{3}$ Institute of Oceanographic Sciences Deacon Laboratory, Brook Road, Wormley, Godalming, Surrey GU8 5UB
}

\begin{abstract}
Relative abundance variations of planktonic Foraminifera have been studied for the Late Miocene to Early Pliocene time interval of 7.0 to $3.5 \mathrm{Ma}$ from three sites in the North East Atlantic; DSDP $607\left(41^{\circ} \mathrm{N}\right)$, DSDP $609\left(50^{\circ} \mathrm{N}\right)$ and DSDP $611\left(53^{\circ} \mathrm{N}\right)$. Particular attention has been given to the percentage of benthic Foraminifera of total (benthic + planktonic) Foraminifera as an index of dissolution by aggressive bottom waters, and to the percentage of dextral Neogloboquadrina pachyderma of total (dextral + sinistral) N. pachyderma as an index of "Sub-Polar" or warmer waters.

Strong dissolution, probably associated with the northward penetration of aggressive Antarctic Bottom Water, is observed at two of the sites up to and during the initiation of the Messinian "Salinity Crisis" in the adjoining Mediterranean Sea at about 5.8 Ma. All three sites exhibit strong cyclic fluctuations of the percentage of dextral N. pachyderma during the Messinian "Salinity Crisis" interval, from approximately $5.8 \mathrm{Ma}$ to $4.8 \mathrm{Ma}$. These are interpreted as indicating wide-ranging oscillations of a water mass boundary, analogous to the present-day Polar Front, in the North Atlantic during the "Salinity Crisis". Following the re-filling of the Mediterranean with normal marine waters at about $4.8 \mathrm{Ma}$, the dextral form of N. pachyderma, which is more characteristic of warmer waters than the sinistral form, becomes the dominant form and shows less quantitative variation at all three sites throughout the Early Pliocene.
\end{abstract}

\section{INTRODUCTION.}

This paper presents the results of an investigation of North Atlantic surface water masses, for the period 7.0 to $3.5 \mathrm{Ma}$ (Late Miocene-Early Pliocene), based on planktonic Foraminifera obtained from Sites 607, 609 and 611 of DSDP Leg 94 (Fig. 1 and Table 1).

Previous work on Late Pleistocene (0.9-0 Ma) and Late Pliocene (2.6-2.3 Ma) samples from DSDP Site 552A (Hooper \& Funnell, 1987) has indicated that a simple form of transfer function analysis, using pre-Late Pleistocene analogue species, combined with coiling ratios of Neogloboquadrina pachyderma (sinistral) to $N$. pachyderma (dextral), provides a very reasonable interpretation of surface water characteristics for the Late Pliocene that is highly correlated with the $\partial^{18} \mathrm{O}$ record.

Because of the variable effect of dissolution on planktonic foraminiferal assemblages at two of the three sites investigated, in the present study attention is focussed on the interpretation of variations in the coiling ratios of $N$. pachyderma. The results of quantitative studies of whole planktonic foraminiferal assemblages are contained in Hooper (1988).

Of the three sites studied, Site 607 , on the western flank of the Mid-Atlantic Ridge in a present-day water depth of 3426 metres, shows negligible evidence of dissolution. Site 609,

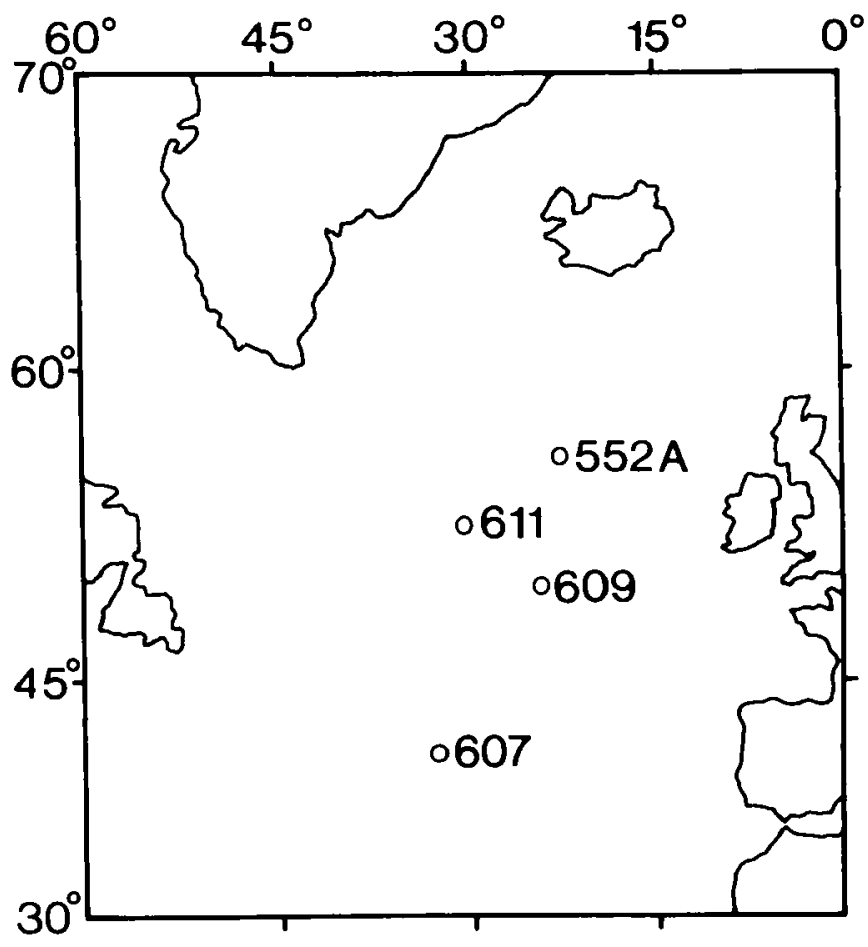

Fig. 1. Location of sites studied in the North Atlantic. 
from the eastern flank of the Mid-Atlantic Ridge at 3883 metres present-day water depth, and Site 611 , from the southeastern flank of the Gardar Drift at 3227 metres present-day water depth, both show significant dissolution from about $6.8 \mathrm{Ma}$ at 611 , (about $6.6 \mathrm{Ma}$ at 609 ) to about $5.8 \mathrm{Ma}$ at both sites.

All numerical ages used in this paper are from the magnetic stratigraphy based time-scale adopted for the sites by Leg 94 scientists (Ruddiman, Kidd, Thomas et al., 1987). Sample numbers and depths in metres below sea floor are listed in Hooper (1988).

Table 1. Deep Sea Drilling Project (DSDP) Site Locations and Water Depths.

\section{DSDP Leg No. Site Latitude Longitude Water Depth (m)}

$\begin{array}{lllll}81 & 552 & 56^{\circ} 02.56^{\prime} \mathrm{N} & 23^{\circ} 13.88^{\prime} \mathrm{W} & 2301 \mathrm{~m} \\ 94 & 607 & 41^{\circ} 00.07^{\prime} \mathrm{N} & 32^{\circ} 57.55^{\prime} \mathrm{W} & 3426 \mathrm{~m} \\ 94 & 609 & 49^{\circ} 52.67^{\prime} \mathrm{N} & 24^{\circ} 14.29^{\prime} \mathrm{W} & 3883 \mathrm{~m} \\ 94 & 611 & 52^{\circ} 50.15^{\prime} \mathrm{N} & 30^{\circ} 19.10^{\prime} \mathrm{W} & 3227 \mathrm{~m}\end{array}$

\section{MIO-PLIOCENE DISSOLUTION RECORD OF THE NORTHEASTERN ATLANTIC.}

Calcite, including the skeletal remains of planktonic Foraminifera and coccolithophorids, is completely dissolved from sediments accumulating in the deep ocean. The depth at which the rate of solution begins to accelerate is known as the lysocline, and the (greater) depth at which the rate of supply of calcite is exactly balanced by the rate of solution, (i.e. below which no calcite is preserved), is known as the Calcite Compensation Depth (CCD). The depth of the CCD in the modern ocean varies from place to place, but generally ranges between 4.5 and $5 \mathrm{~km}$ in the open ocean. The depth of the CCD is also known to vary over geological time in response to overall changes in oceanic chemical equilibria. The determination of whether past sediments were accumulated above or below the CCD is easily carried out by chemical analysis. However degrees of dissolution shown by sediment accumulated just above the CCD can best be determined by the effects of solution on the differential solubility, and therefore differential preservation, of different taxa of calcitic microfossils (Berger, 1970, 1983). Because in general planktonic Foraminifera are more susceptible to dissolution under deep-sea conditions than benthic Foraminifera, the normally very low percentage of benthic Foraminifera in total deep-sea foraminiferal assemblages increases under conditions of increased dissolution. This percentage can therefore be used as an approximate index of the degree of dissolution that a deep-sea sediment has undergone. In Fig. 2 the percentage benthics in the total foraminiferal assemblages has been plotted against time for each of the Sites 607,609 and 611 for the period from approximately 7.0 to 3.5 Ma. This period covers the latest Miocene and most of the Early Pliocene, including the time of the Messinian "Salinity Crisis" in the adjoining Mediterranean Sea.

Site 607 is a relatively shallow site, $(3426 \mathrm{~m}$ water depth at the present day), and shows no signs of dissolution of calcite throughout the period studied.

Site 609 is less shallow, ( $3883 \mathrm{~m} \mathrm{pdwd})$, and there are clear signs of dissolution, (high or very high percentages of benthic Foraminifera), from about 6.6 to $5.8 \mathrm{Ma}$, with major dissolution peaks at 6.4 and $6.0 \mathrm{Ma}$. Slight peaks of dissolution occur at intervals until the end of the record at about $4.3 \mathrm{Ma}$.

At Site $611,(3227 \mathrm{~m}$ pdwd, but close to the Gibbs Fracture Zone, which forms one of the major pathways for $A A B W$ as it flows from the western to the eastern North Atlantic Basin), a similar record to that at Site 609 occurs. Marked, but not quite as extreme dissolution as at Site 609 , occurs from about 6.8 to $5.8 \mathrm{Ma}$, with significant peaks at $6.7,6.4$ and $6.1 \mathrm{Ma}$. The last two peaks are more or less coincident with those noted in Site 609. Again, only minor dissolution peaks occur after $6.0 \mathrm{Ma}$, and after 4.3 Ma there is practically no indication of dissolution at all.

The main source of $\mathrm{CO}_{2}$-rich bottom water thought to be responsible for calcite solution in the northeastern Atlantic in the Late Miocene is the Antarctic Bottom Water (AABW), originating around the Antarctic during a time of significant expansion of Antarctic glaciation. The episodes of dissolution seen at Sites 609 and 611 are likely therefore to be produced by pulses of chemically "aggressive" AABW driven by intensification of glaciation on and around the Antarctic continent during the late Miocene. Barron \& Keller (1982) attribute a major hiatus in ocean sedimentation (NH6) to a major dissolution pulse associated with the expansion of the Antarctic ice cap between 7.5 and $6.2 \mathrm{Ma}$. It is noticeable that the main episodes of dissolution in the northeastern Atlantic pre-date the main sequence of Messinian "Salinity Crisis" events in the Mediterranean, suggesting that the northward penetration of AABW was less marked during the period of opening and closing of the Mediterranean connection with the North Atlantic than it had been immediately previously.

\section{SURFACE WATER PALAEOTEMPERATURE ANALYSIS.}

In a previous paper, which explored the possibility of applying quantitative analysis of planktonic Foraminifera to the interpretation of pre-Late Pleistocene surface water temperatures (Hooper \& Funnell, 1987), it was discovered that the parameter which proved most highly correlatable with the ${ }_{-}^{18} \mathrm{O}$ record was the coiling ratio of sinistral to dextral forms in the genus Neogloboquadrina. Hooper and Funnell (1987) extended the relationship between coiling directions and palaeotemperatures back into the Late Pliocene, prior to the extinction of the earlier species of Neogloboquadrina, $N$. atlantica.

The importance of the genus Neogloboquadrina in late Cenozoic North Atlantic assemblages has been discussed in detail by Hooper \& Weaver (1987). Its significance for late Cenozoic 
Hooper, Funnell, and Weaver

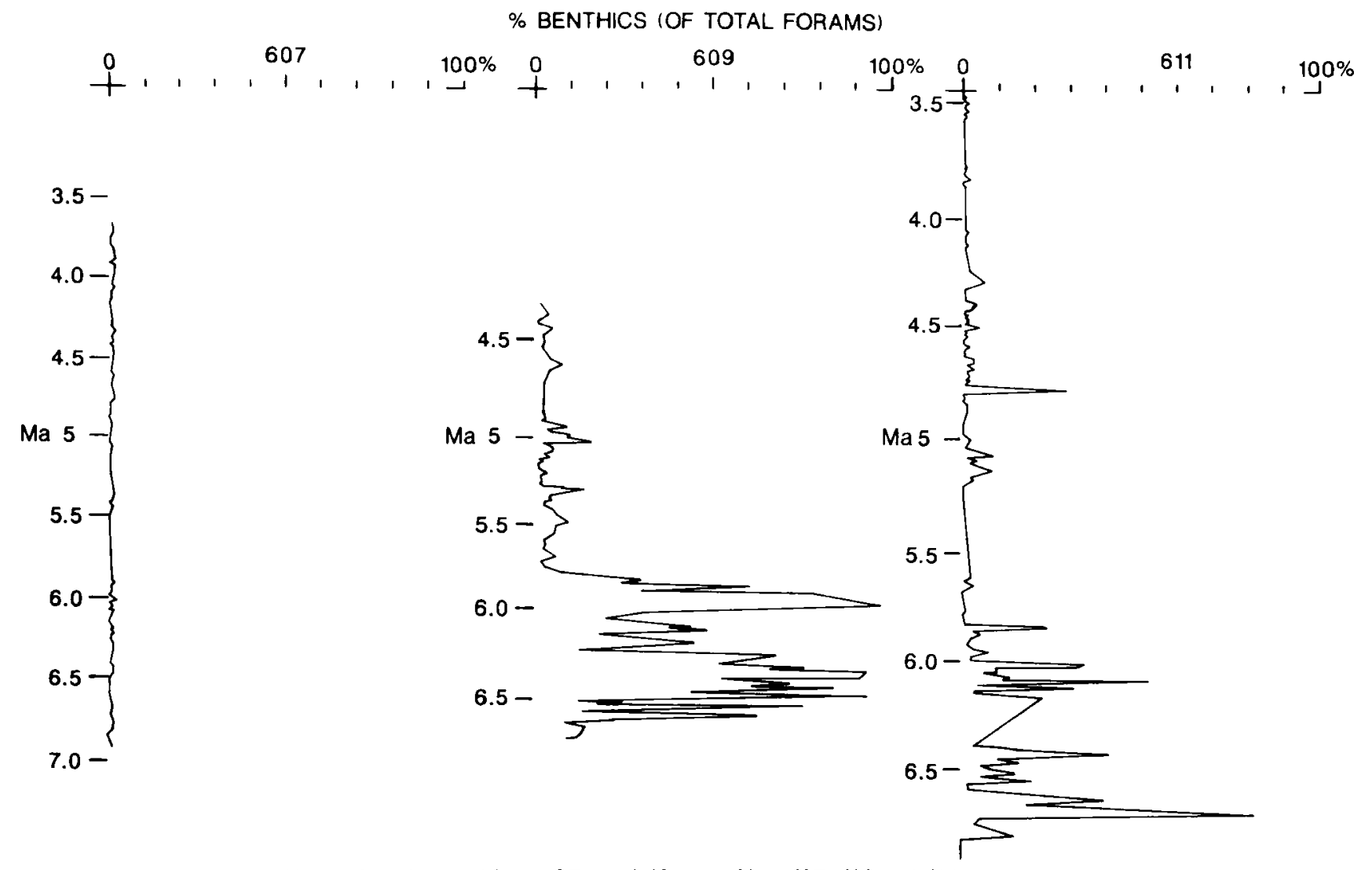

Fig. 2. \%Benthic Foraminifera (of total assemblage of Foraminifera) at Sites 607,609 and 611.

\% DEXTRAL N. PACHYDERMA

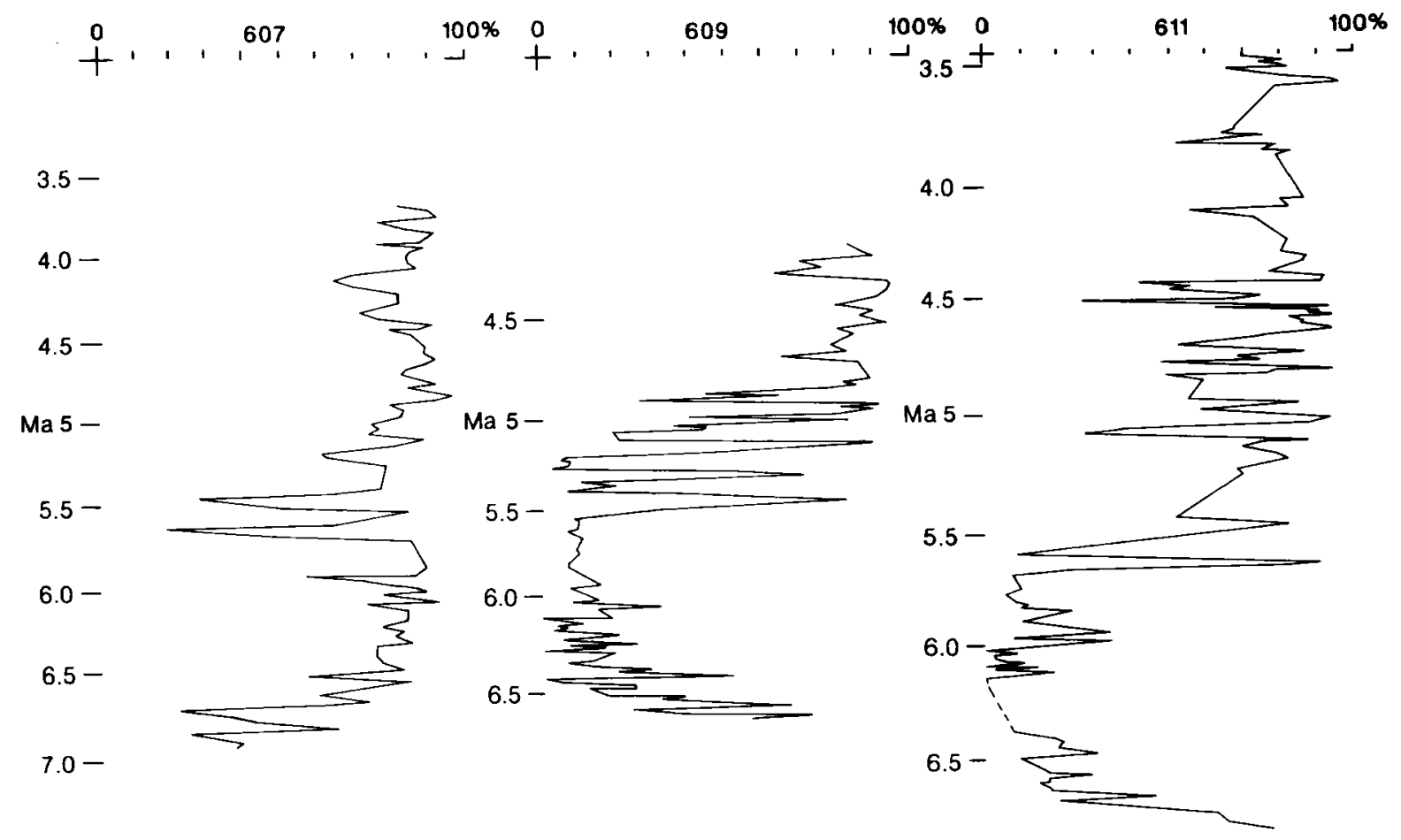

Fig. 3. Cyclical variation in the \%N. pachyderma (dextral) of total N. pachyderma at Sites 607, 609 and 611 , for the period 7.0-3.5 Ma. 
palaeoclimatic reconstructions at higher latitudes can scarcely be over-emphasised. It frequently dominates planktonic foraminiferal assemblages at higher latitudes for two reasons: firstly it is one of the few genera of planktonic Foraminifera that is tolerant of cooler surface ocean waters, and secondly its species are dissolution-resistant and therefore tend to be concentrated in bottom sediments subject to moderate dissolution. The impact of dissolution on our samples from Sites 609 and 611 has already been described. In these circumstances it is difficult to make valid comparisons between sites based on the total planktonic foraminiferal assemblages as they are inevitably biased by dissolution. On the other hand there appears to be no differential solution effect between the sinistral and dextral forms of N. pachyderma, which in the Miocene and Pliocene have identical morphologies (Plate 1). Therefore, in this study the coiling ratio of $N$. pachyderma has been used preferentially for between site comparisons of inferred surface water temperature fluctuations, rather than attempting an interpretation of the total planktonic foraminiferal assemblage.

In Fig. 3 we present the values for the coiling ratio of dextral to sinistral $N$. pachyderma, (as percentage dextral of total $N$. pachyderma), for all three Sites 607,609 and 611 for the period from about 7.0 to $4.0 \mathrm{Ma}$.

From 7.0 to about 5.8 Ma the ratio shows a progressive decline at the two northernmost sites $(609$ and 611$)$, whereas at the southernmost site (607) it increases. At the present day the proportion of dextral $N$. pachyderma is consistently higher than $70 \%$ in sediments underlying Sub-Polar surface waters, whereas it is less than $30 \%$ under Polar waters. Therefore the coiling ratio results prior to $5.8 \mathrm{Ma}$ at Site 607 indicate generally warmer surface waters than at Sites 609 and 611, (but with indications for a recovery from significantly colder surface water conditions at Site 607 at around 6.7 to $6.8 \mathrm{Ma}$ ). The date of 5.8 Ma marks the end of the episode of maximum dissolution, presumed to have been caused by maximum northward penetration of AABW into the North Atlantic recorded at Site 611 (Fig. 2). At the two northern sites the decline in dextral $N$. pachyderma, from a initial peak at about $6.6 \mathrm{Ma}$, seems to imply the establishment of a strong contrast between surface water temperatures at Sites $609+611$ and 607 during the period 6.5 to $5.8 \mathrm{Ma}$, compared with the periods immediately before and after.

From 5.8 Ma onwards we observe strong cyclical variations in the percentages of dextral $N$. pachyderma at all three sites. It is difficult to be precise about the synchroneity of the oscillations at all three sites because of the spacing of samples and the overall uncertainties inherent in the timescales applied to the sites. However, making the most reasonable assumptions 5 distinct cycles seem to be present. Not all of the cycles are equally well represented at all sites; our favoured interpretation is highlighted in Fig. 4 and Table 2. Since we consider it highly likely that these cycles are closely connnected with the sequence of opening and closing of the Atlantic connection with the Mediterranean during the Messinian "Salinity Crisis" further discussion is grouped under that heading.

Table 2. \%dextral N. pachyderma minimum cycles identified at Sites 607,609 and 611 between 5.8 and $4.8 \mathrm{Ma}$.

Cycle No.Estimated AgeSites* in which recognised

$\begin{array}{lll}\text { C15.8 Ma(607) } & 609 & 611 \\ \text { C25.6 Ma 607 } & 609 & 611 \\ \text { C35.4 Ma 607 } & 609 & 611 \\ \text { C45.2 Ma 607 } & 609 & (611) \\ \text { C55.05 Ma 607 } & 609 & 611 \\ \text { C64.9 Ma(607) } & 609 & 611\end{array}$

(*Where the Site number is in brackets, either the cycle is apparently absent, or the sampling interval is too large to resolve it.)

\section{RELATION OF THE NORTH ATLANTIC RECORD TO THE MESSINIAN "SALINITY CRISIS".}

In Fig. 4 we identify the possibility of a total of 6 cycles ( $\mathrm{C} 1$ to C6) over an interval of approximately $1 \mathrm{Myr}$, from 5.8 to 4.8 Ma. Our best estimate of the ages of the cycles and their representation at the different sites is indicated in Table 2.

Cycle C1, present at the northernmost Sites 609 and 611 , constitutes a trough in occurrence of dextral $N$. pachyderma, and presumed surface water cooling at about $5.8 \mathrm{Ma}$, following warmer but declining surface water temperatures during the previous $1 \mathrm{Myr}$ from 6.8 Ma onwards. No equivalent cooling is apparent at Site 607 at this time and a significant water mass boundary may be inferred to have existed between the northernmost sites and the southern site prior to $5.8 \mathrm{Ma}$.

Sharp fluctuations, with cooler surface water conditions (dextral $N$. pachyderma forming less than $70 \%$ and usually less than $30 \%$ of the population) occur on four subsequent occasions at all three sites at about 5.6 Ma, 5.4 Ma, 5.2 Ma and 5.05 Ma, followed by a final cool cycle, (which may or may not be recorded at the southern Site 607, but is certainly present at the northernmost sites), at about 4.9 Ma.

The precise timing of the Messinian "Salinity Crisis" has been much studied and much debated. The most recent assessment, closely linked to magneto-stratigraphic determinations on Messinian sediments recovered during ODP Leg 107 operations in the Mediterranean Tyrrhenian Sea, has been made by Kastens \& Mascle (1990). They infer (pp.12, 22) an age of about $6.5 \mathrm{Ma}$ for the base of the Messinian, with the onset of evaporite deposition (the "Salinity Crisis" itself) occurring 'several hundred thousand years' later. The re-establishment of normal marine conditions in the Mediterranean at the beginning of the Pliocene is dated (ibidem, p.14, 22) at about $4.8 \mathrm{Ma}$. These dates correspond closely with the 1 Myr interval of sharp fluctuations in the \%dextral $N$. pachyderma at Sites 607,609 and 611 , commencing with cycle $\mathrm{C} 1$ centered on $5.8 \mathrm{Ma}$ 


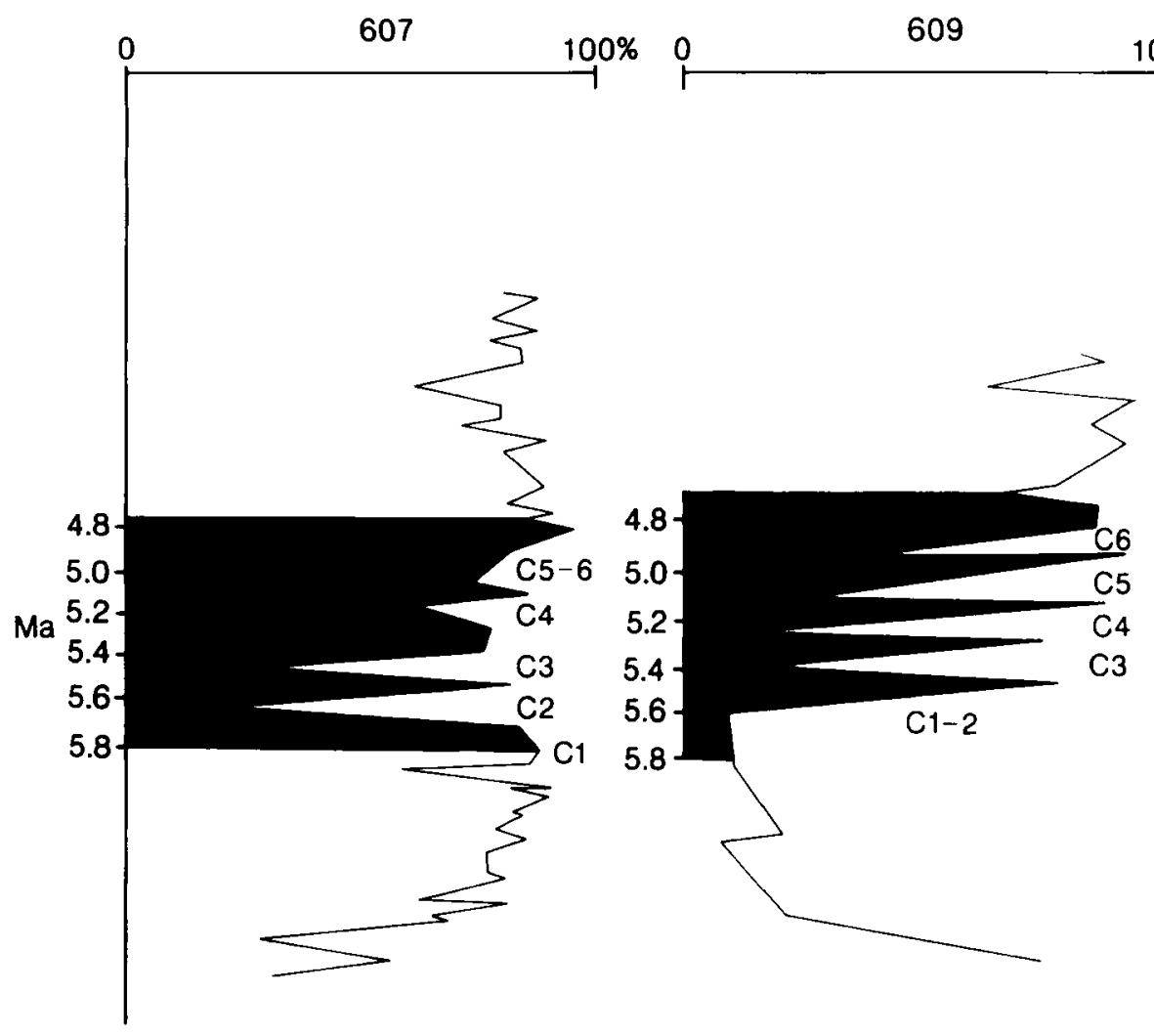
$100 \%$

611

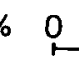

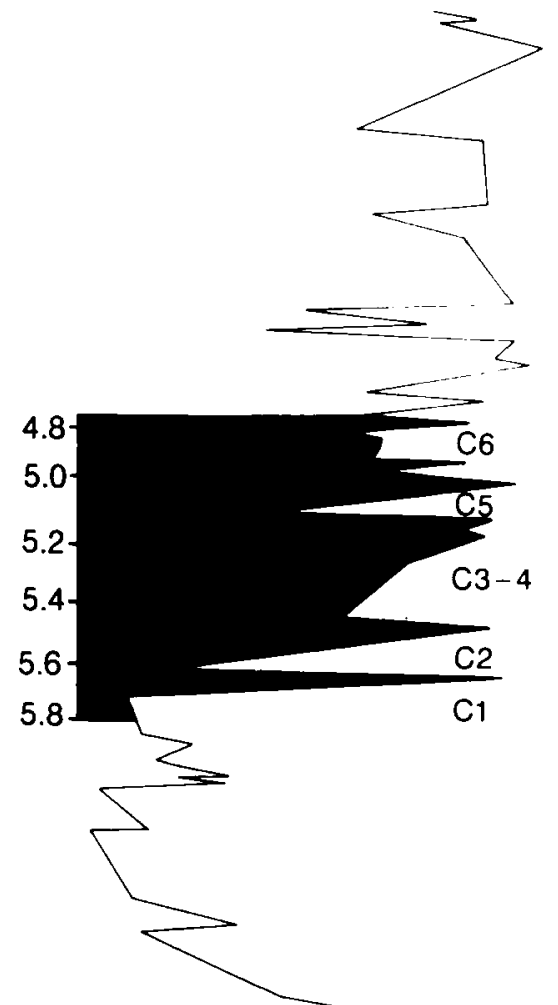

Fig. 4. Cyclical variation in the \%N. pachyderma (dextral) at Sites 607,609 and 611, centered on the period 5.8-4.8 Ma.
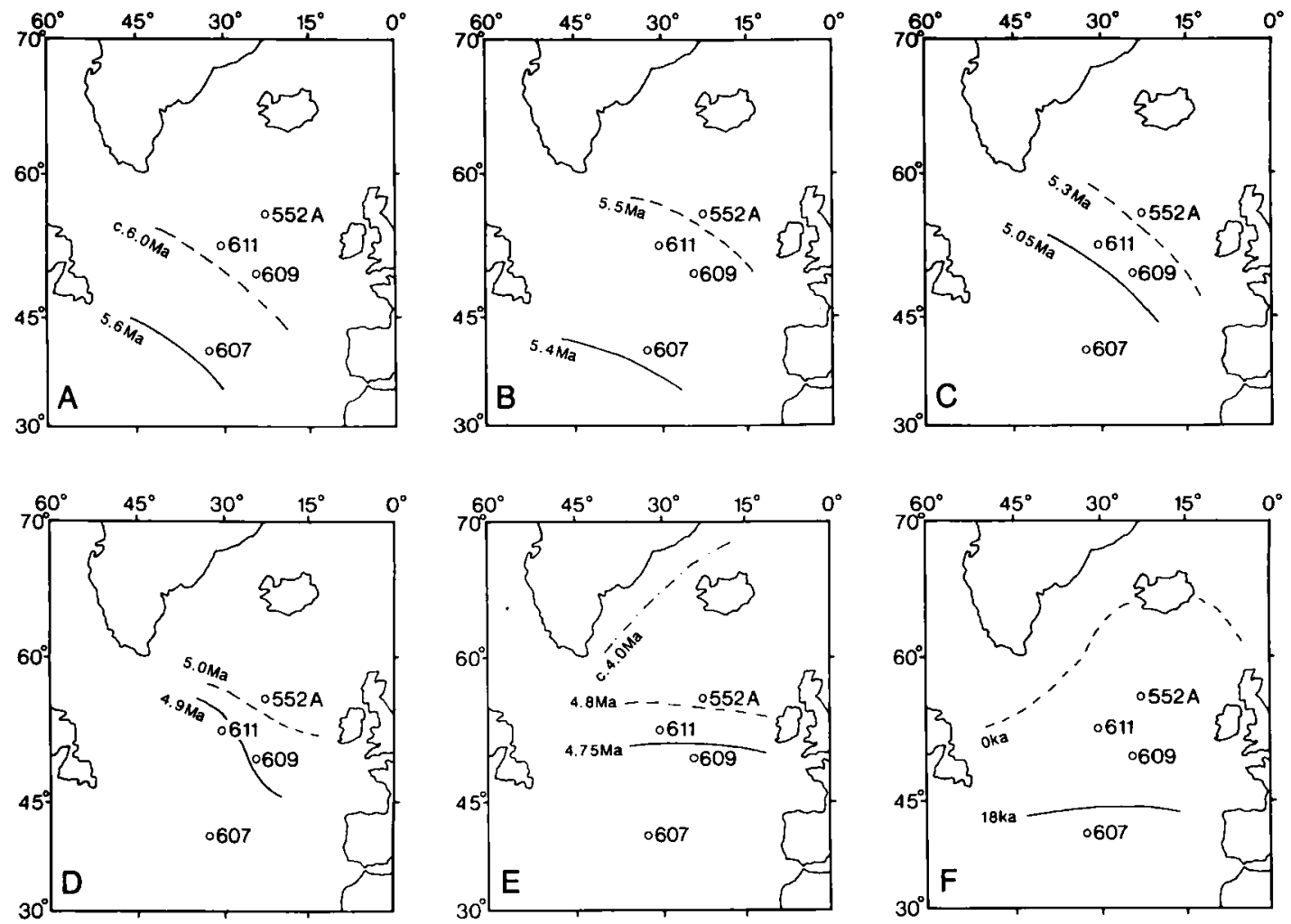

Fig. 5. Apparent migration of analogue "Polar Front" from 6.0 Ma to 4.0 Ma, compared with the Polar Front at 18 and 0ka. A. 6.0-5.6 Ma; B. 5.5-5.4 Ma; C. 5.3-5.1 Ma; D. 5.0-4.9 Ma; E. 4.8-c.4.0 Ma; F. Polar Front at 18 and 0 ka. 
(=onset of "Salinity Crisis" several hundred thousand years after the start of the Messinian), and concluding with cycle C6 centered on $4.9 \mathrm{Ma}$ (immediately preceding the restoration of normal marine conditions in the Mediterranean at $4.8 \mathrm{Ma}$ ).

It is possible to interpret the coiling ratio variations at Sites 607 , 609 and 611 , not only in terms of temporal variation, but also in terms of spatial variation. If, for the time being, we ignore the morphological differences between the Late Pleistocene and Mio-Pliocene forms of $N$. pachyderma, and the potential differences in surface water temperature tolerance that this may imply, we can experiment with taking the greater than $70 \%$ dextral $N$.pachyderma as indicating occupancy of surface waters on the warm side of a quasi-Polar Front in "Sub-Polar" conditions, and less than $30 \%$ as indicating a position on the cool side of a quasi-Polar Front under "Polar" conditions. The results are mapped in Fig. 5.

The two southernmost excursions of the "Front" (Fig. 5A and Fig. 5B) at 5.6 Ma and 5.4 Ma are likely to correspond in time with the early evaporites of the Mediterranean "Salinity Crisis". The later excursions (Fig. 5C and Fig. 5D) at 5.05 Ma and $4.9 \mathrm{Ma}$ are likely to correspond with the complex variations in conditions of the latter part of the "Salinity Crisis". The more northerly position of the inferred front, from $4.8 \mathrm{Ma}$ onwards (Fig. 5E) corresponds with the restoration of normal marine conditions in the Mediterranean. These fluctuations in North Atlantic surface water conditions would be consistent with the possibility of glacio-eustatic control on the sequence of Messinian "Salinity Crisis" deposits in the Mediterranean, as well as on its initiation.

Following the end of the Messinian "Salinity Crisis", and with the re-occupation of the Mediterranean Basin by normal marine waters, the surface waters of the North Atlantic became consistently warm for the duration of the Early Pliocene, as indicated by the consistently high values of dextral $N$. pachyderma for all three sites studied up to $3.5 \mathrm{Ma}$. As envisaged above, this implies that any quasi-Polar Front retreated poleward of Site 611 in the North Atlantic throughout the period of warm climate which characterised the Early Pliocene.

\section{ACKNOWLEGEMENTS.}

P. W. P. Hooper was supported by an NERC "CASE" Research Studentship at the University of East Anglia and the Institute of Oceanographic Sciences Deacon Laboraratory. P.P.E. Weaver participated as shipboard scientist on DSDP Leg 94.

\section{Manuscript received November 1989 \\ Revised manuscript accepted July 1990}

\section{REFERENCES.}

Barron, J. A., and Keller, G., 1982, Widespread Miocene deep-sea hiatuses: coincidence with periods of global cooling. Geology, 10, 577-581.

Berger, W. H., 1970, Planktonic Foraminifera: selective solution and the lysocline. Marine Geology, 8, 111-138.

Berger, W. H., 1983, Planktonic Foraminifera: selective solution and paleoclimatic interpretation. Deep-Sea Res., 15, 31-48.

Hooper, P. W. P., 1988, Late Neogene Planktonic Foraminifera and Palaeoceanography of the North Atlantic. PhD. thesis, University of East Anglia, 359 pp.

Hooper, P. W. P., and Funnell, B. M., 1986, Late Pliocene to Recent planktonic foraminifera from the North Atlantic (DSDP Site 552A): quantitative palaeotemperature analysis. Geological Society Special Publication, No. 21, 181-190.

Hooper, P.W.P., and Weaver, P.P.E., 1987, Late Neogene species of the genus Neogloboquadrina Bandy, Frerichs and Vincent in the North Atlantic: a biostratigraphic, palaeoceanographic and phylogenetic review. In Hart, M. (Ed.), The Micropalaeontology of Carbonate Environments, pp.21-43. Ellis Horwood. Chichester.

Kastens, K.A. and Mascle, J. 1990. The Geological Evoloution of the Tyrrehenian Sea: an introduction to the Scientific Result of Leg 107. In Kastens, K.A., Mascle, J. et al., Proc. ODP Sci. Results, 107: College Station, TX. (Ocean Drilling Programme), 3-26.

Ruddiman, W. F., Kidd, R. B. , Thomas, E., et al., 1987, Init. Repts DSDP, 94: Washington (U.S. Govt. Printing Office).

\section{Explanation of Plate 1}

Figs. 1-4. Neogloboquadrina pachyderma, dextral 'normal' form (DSDP Site 552A, 1/1/20) (Pleistocene). Fig. 1. umbilical view, x280. Fig. 2. lateral view, x280. Fig. 3. spiral view, x260. Fig. 4. surface ultrastructure, x 1,000. Figs. 5-8. Neogloboquadrinapachyderma, dextral encrusted form (DSDP Site 611, 8/4/143) (latest Pliocene). Fig. 5. umbilical view, x370. Fig. 6. lateral view, x370. Fig. 7. spiral view, x400. Fig. 8. surface ultrastructure, $x$ 1,500. Figs. 9-12. Neogloboquadrina pachyderma, sinistral encrusted form (DSDP Site 552A. 1/1/20) (Pleistocene). Fig. 9. umbilical view, x280. Fig. 10. lateral view, x280. Fig. 11. spiral view, x280. Fig. 12. surface ultrastructure, x1,000. Figs. 13-16. Neogloboquadrina pachyderma, sinistral 'normal' form (DSDP Site 609,41/1/110) (Late Miocene). Fig. 13. umbilical view. x280. Fig. 14. lateral view, x280. Fig. 15. spiral view, x280. Fig. 16. surface ultrastructure, xl,000. Figs. 17-20. Neogloboquadrina pachyderma, dextral 'normal" form (DSDP Site 609, 42/3/110) (Late Miocene). Fig. 17. umbilical view, x280. Fig. 18. lateral view, x280. Fig. 19. spiral view, x280. Fig. 20. surface ultrastructure, $x 1,000$. 


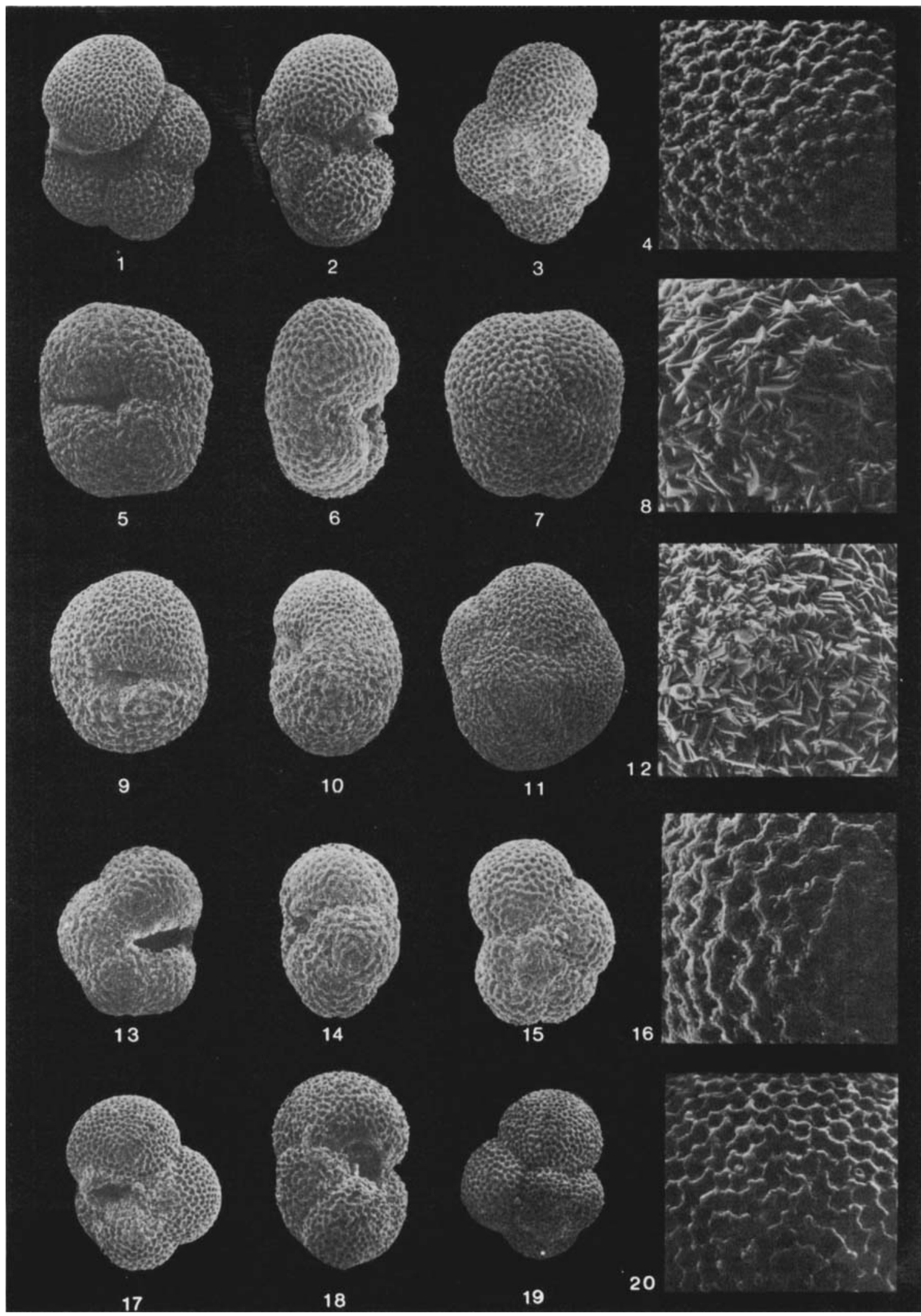

